\title{
Accessibility applied to ships, case study Riverine Ambulatory Care Center (RACC)
}

\author{
Accesibilidad aplicada a embarcaciones, caso de estudio
} Centro de Atención Ambulatoria Fluvial (CAAF)

\begin{abstract}
Accessibility as a design concept is generally applied in land constructions; however, the medical character of the case study requires it to be considered in the design process as of its conceptual stage. The riverine ambulatory care center (RACC) is a mobile health unit to carry out medical missions in populations located on the riverbanks; given the RACC dimensions, these have limited medical services to primary care and health brigades. Physical barriers $^{1}$ are the causes for an environment being inaccessible; to eliminate them, from the RACC, an analysis and redesign was performed of the conceptual proposal, based on standards for accessibility, medical spaces, and ships. Two basic moments were taken for intervention, access and interior circulation, yielding as a result the design of an integrated system of products that eliminate the physical barriers from the environment, permitting boarding and offering medical services under equal, comfortable, and safe conditions. Accessibility as modifier of the environment to improve the quality of life of users should not only be applied in medical ships, this study opens an opportunity for industry to optimize the physical environment of other types of ships by applying this concept.
\end{abstract}

Key words: Accessibility, hospital ship, universal design, support products, reduced mobility, Riverine ambulatory care center (RACC)

\section{Resumen}

La accesibilidad como concepto de diseño se aplica generalmente en las construcciones en tierra, sin embargo, el carácter médico del caso de estudio requiere que sea considerado en el proceso de diseño desde su etapa conceptual. El Centro de Atención Ambulatoria Fluvial (CAAF) es una unidad sanitaria móvil para realizar misiones médicas en poblaciones ubicadas en la ribera de los ríos, por las dimensiones del CAAF han limitado los servicios médicos a atención primaria y brigadas de salud. Las barreras físicas ${ }^{1}$ son las causantes de que un entorno no sea accesible, para eliminarlas del CAAF, se realizó un análisis y rediseño de la propuesta conceptual, apoyado en la normativa para accesibilidad, espacios médicos y embarcaciones. Se tomaron dos momentos básicos a intervenir, el acceso y la circulación interior, dando como resultado el diseńo de un sistema integrado de productos que eliminan las barreras físicas del entorno, permitiendo un abordaje y prestación de los servicios médicos en condiciones iguales, confortables y seguras. La accesibilidad como modificador del entorno para mejorar la calidad de vida de los usuarios no debe ser aplicado solamente en embarcaciones médicas, con este estudio se abre una oportunidad para la industria de optimizar el entorno físico de otros tipos de embarcaciones, por medio de la aplicación de este concepto.

Palabras claves: Accesibilidad, buque hospital, diseño universal, productos de apoyo, movilidad reducida, Centro de Atención Ambulatoria Fluvial (CAAF).

\footnotetext{
1 Physical obstacles of the constructed environment that keep certain population groups from reaching, accessing, or moving throughout the particular building, place or zone. (University Institute of European Studies, Universidad Autónoma de Barcelona. Spanish Ministry of Labor and Social Issues, 2002).

${ }^{1}$ Obstáculos físicos del entorno construido que impiden que determinados grupos de población puedan llegar, acceder o moverse por un edificio, lugar o zona en particular. (Instituto Universitario de Estudios Europeos, Universidad Autónoma de Barcelona. Ministerio de Trabajo y Asuntos Sociales de España, 2002)
}

Date Received: May 23th, 2012 - Fecha de recepción: 23 de Mayo de 2012

Date Accepted: September 19th, 2012 - Fecha de aceptación: 19 de Septiembre de 2012

${ }^{1}$ Corporación de Ciencia y Tecnología para el Desarrollo de la Industria Naval, Marítima y Fluvial COTECMAR. e-mail: dlgonzalez@cotecmar.com

${ }^{2}$ Corporación de Ciencia y Tecnología para el Desarrollo de la Industria Naval, Marítima y Fluvial COTECMAR. e-mail: pareiza@cotecmar.com 


\section{Introduction}

In recent years, COTECMAR has been requested by diverse entities to design medical ships, which has led to the emergence of the riverine ambulatory care center, which is in the conceptual design phase using as a base for its development the hull of the mothership-type River Patrol Support Ship (PAF-P).

However, its physical environment does not afford the suitable conditions to enter, circulate, and exit by using support products ${ }^{1}$ like wheel chairs; difficulties like circulating the ramps between the pier and the ship or doors with inadequate dimensions are evident, generating a large amount of physical barriers that would hinder access of users to medical services, which goes completely against the RACC's final objective of offering the populations on the riverbanks an essential and indispensable theme to generate an inclusive environment that improves the quality of life, autonomy, and safety of users on board.

The problem of accessibility in ships has not been previously studied in the national industry, making it necessary to approach it as of constructions on land, specifically hospitals in which it has been studied in depth, emphasizing on individuals with reduced mobility; however, ships have by their very nature some characteristics that affect the arrangement of the physical space that must be considered to perform an accurate analysis, the structural requirements affecting the interior space, constant movement caused by navigation, and the high safety standards required, among others. From these aspects, the case study was analyzed, which defined two scenarios as a starting point: access and interior circulation.

The case study analysis concludes in eliminating the physical barriers; in the first instance, the proposal for access is the location of several products on the forecastle among which is highlighted a support

\footnotetext{
Instruments or special devices that permit carrying out diverse activities that without such aid would be left without possibility, that is, they are facilitating elements that help individuals to get as close as possible to normality, starting from their deficient capacity, transforming the environment to favor the integration of individuals with diverse deficits.
}

product specially designed for the ingress of patients on wheelchairs or stretchers; regarding circulation, the general disposition was optimized according to the relationship of the medical services, to facilitate movement of patients, inputs and hospital wastes.

The following presents the analysis process and the design results in the RACC, which can be taken as reference for other studies.

\section{Accessibility, definition, and strategies}

Accessibility is a concept that has achieved particular importance during recent years in the architectural field; supported by different entities and initiatives that promote equality independent of each individual's physical, sensory, or emotional conditions, the concept has several definitions according to the point of view assigned to it, this specific case emphasizes the relationship between subjects and their surroundings:

"Accessibility is the set of characteristics that must be present in an environment, product, or service to make it usable under conditions of comfort, safety, and equality by all people and, particularly, by those who have some disability." (Ministry of Labor and Social Issues. Alonso, Fernando, 2003)

Accessibility becomes perceptible with the appearance of barriers ${ }^{3}$ that cause its absence and - consequently - discrimination, social exclusion, and reduction of comfort; various types of barriers may be mentioned: intrinsic, environmental, and interactive (Smith, 1987) associated to the subject, the context, and their interaction, respectively, the last is the most visible given that it is manifested everyday from architecture, urbanism, transportation, and telecomunications (Amengual, 1996); it is notable that it is not merely about a single context, which is why the vision of accessibility must be systemic to provide

\footnotetext{
2 People with disability include those with long-term physical, mental, intellectual, or sensory deficiencies that, upon interacting with diverse barriers, can impede their full and effective participation in society, in equal conditions with the rest." (United Nations, 2007) 3 Barriers like expression of obstacles that causes the functional differences among people to become inequalities. (Alonso, 2007)
} 
comprehensive solutions in all situations that so require it.

As an emerging tendency corresponding to the need to approach the theme from a comprehensive vantage point we have the rehabilitation technologies (University Institute of European Studies, Universidad Autónoma de Barcelona, 2002) defined as:

"Any technology from which products, instruments, equipment, or technical systems may be derived accessible by disabled individuals andlor the elderlywhether these are produced specially for them or with a general character - to avoid, compensate, mitigate, or neutralize the deficiency, disability, or handicap and improve personal autonomy and quality of life." (Swedish Handicap Institute, 1994).

For the practical application of these technologies - until now under development, two strategies are identified applied to the design of environments, products, or services:

- Universal design: "Understand as Universal design the design of products and environments suitable to being used by the greatest number of people without need for adaptations or for a specialized design" (North Carolina State University, 1995)

- Design of technical aids or support products: "When reduced ability or capacity to handle that product reaches a given level, it will be necessary to follow a more specific strategy, which consists of designing special products or systems for people with a considerable loss of ability" (University Institute of European Studies, Universidad Autónoma de Barcelona, 2002)

Thus, we may speak of the onset of degrees of accessibility because it is evident that the universal design is the ideal solution, but its application is not viable in all cases; applying one or another strategy depends on diverse factors like:

- Decrease or loss of certain ability to relate to the environment, the greater loss requires the solution to be more specific and it will be applied whenever no other reasonable mean is available to solve the problem.

- Environmental demands, given that on occasion the structural, environmental, or dimensional conditions of the space do not permit the design of a universal solution.

These degrees evidence how equal the environment, service, or product turn out (Alonso, 2007) to comfortably and safely relate regardless of the individual's condition, the degrees can be the result of the combination of both strategies applied in a specific situation.

There is an additional aspect to the problem of accessibility and it is most pertinent in its application on ships: limits, it is essential to consider every effort and means employed in the development of accessible solutions in relation to its results, consequences, and benefits (Alonso, 2007) within a specific context; limits determine the pertinence of investing economic, human, and time resources, given that in every project resources are limited and their best use must be sought. Design of accessible solutions from the environment results in many cases economically costly and its benefit is not notable against such an investment; however, the mere fact of considering the equality of conditions as a universal ${ }^{4}$, ethical, legal, and socially nonnegotiable principle is sufficient for its pertinence to be assessed and for it to be considered a priority within a list of requirements of a project or design from its start and not as a final repair that results in a poorly efficient adaptation.

By contextualizing the aforementioned to the Colombian case, the 2005 census found a 6.3\% prevalence of individuals with some limitation, that is, that considering the total population for Colombia during that same year $(42,090,502)$, it is calculated that there were 2,651,701 people in the country with at least one limitation; of these $76 \%$ perceive architectural barriers in their immediate environment (Colombia Lider, Fundation Saldarriaga Concha, 2010), which makes accessibility a national problem to which

\footnotetext{
4 "Promote, protect, and ensure full enjoyment of human rights and fundamental freedoms under conditions of equality for persons with disabilities, and promote respect for their inherent dignity" (United Nations, 2007)
} 
COTECMAR as a Science and Technology Corporation joins in the research, development, and innovation in favor of equality and social inclusion.

\section{Application in ships}

Basically, we can define four purposes for which ships are designed: as business units to transport diverse products immersed in market dynamics, support of the nation's defense and sovereignty for which warfare units are constructed, passenger ships aimed at tourism, and - lastly - auxiliary service ships that complement the aforementioned.

To evaluate the conditions limiting the application of accessibility within the shipping context, it is important to understand the most relevant characteristics of the spatial arrangement in ship design, among which we find:

- Reduced spaces, in addition to structural requirements being high, requiring habitability to be adapted to these.

- The arrangement of various decks requires vertical mobility, for their disposition it is important to consider the adequate angle de stairs and ladders according to the type of service provided - especially in evacuation routes.

- The ship's watertightness condition does not permit its doors to be located directly on the deck, but to keep a vertical distance (coaming or sill) that prevents water from entering, generating a physical barrier.

- Constant movement during navigation, caused by sea or river conditions ( $\mathrm{drift}$ and pitch due to waves, wind, tides, currents, among others)

- The fact that it is an independent structure temporarily isolated from land, it demands some high safety standards given that it cannot receive immediate attention during emergencies.

- Requirement of a platform on land for boarding and disembarking of people. Boarding conditions can vary according to the site.

- Higher risk of accidents when containing large fuel tanks in engine rooms placed relatively close to habitable zones.

Another of the characteristics of ships affecting the interior design is the on-board population; two types of ships can be differentiated in terms of accessibility, those limited to a trained crew and those that permit access to individuals with reduced mobility.

Given the complexity of keeping the ship navigating safely, the International Maritime Organization (IMO) requires that all crew be trained in firefighting, first aid, survival, and social responsibility to be allowed to navigate, which is why individuals with physical limitations are denied access to merchant, fishing, auxiliary, or war ships in which the design of completely accessible spaces is not viable and the investment is not justifiable against the purpose of the ship; their population is limited to the trained crew, with some exceptions for short periods like boarding of researchers, family members or shipbuilders, as it is common in the case of the merchant marine; boarding of individuals with reduced mobility would increase the investment that is not justified against the ship's purpose.

Regarding passenger ships, specifically cruise ships, yachts, catamarans, and sailboats, boarding is permitted to any person independent of his/her physical condition; however, not all are designed for accessibility, this will depend on the client's specific needs, given that often their finality is not of public access. Cruise ships are - until now - the most advanced ships in this issue, given that they are governed by regulations that obligate them to provide accessible environments, which is why they are generally equipped with elevators, wide corridors, and trained crews to care for special passengers in case of emergency.

These are the two positions the naval industry has regarding accessibility from the point of view of reduced mobility, applications can be found from other perspectives according to the ship's final objective, like optimization of evacuation means, access to confined spaces, and other improvements that reduce the physical barriers increasing on-board safety and comfort. 
This generates in the ships' physical environment special conditions that differ from a structure on land and which should be considered in the design process and - more so - in a ship with the characteristics of the case study where it is vital to provide conditions of equality.

\section{Case study, Riverine Ambulatory Care Center (RACC)}

The riverine ambulatory care center (RACC) is a mobile health unit designed by the $R \& D+i$ Direction (DIDESI) to conduct medical missions in populations located on the riverbanks and that do not have medical services available or with very low level of care. External healthcare advisors helped to design the RACC on the hull of the mothership-type (PAF-P) ship, which is a product designed and constructed by COTECMAR for the Colombian National Navy.

As a hospital ship, it is essential for it to permit embarking and optimal circulation of any individual under conditions of equality, safety, and comfort. Considering accessibility to the physical environment as fundamental part of the design process, an analysis and re-design of the RACC's conceptual proposal was carried out, particularly emphasizing on persons requiring support products for mobility; however, the lack of specific guidelines is notable for hospital ships, which generates an investigation opportunity to offer an innovative solution for an issue that has not been addressed at the national level.

\section{Analisys}

The RACC has laboratory, pharmacy, general medical consultation, gynecology, dentistry, X-ray, minor surgery, operating room, and hospitalization services focused on observation and transfer; these services were defined based on the "Manual of Activities, Interventions, and Procedures of the Compulsory Health Plan in the Healthcare Social Safety General System MAPIPOS" (Ministry of Health, 1994).

With these services in mind, the decks were divided into zones, thus: main deck to provide medical and complementary services (waste storage, health services, reception, among others), deck 2 (below the main) for crew quarters, and deck 01 (above the main) for navigation tasks and the heliport.

\section{Population}

Regarding the population, the term reduced mobility ${ }^{5}$ was taken to define those users who because of some temporary or permanent disability require the use of support products (wheelchairs, canes, prosthesis) to move. These can be classified into ambulatories and non- ambulatories: ambulatories are those who in spite of their reduced capacity to move can walk without the need for a wheelchair, like the elderly, pregnant women, and persons with prosthetic limbs; non-ambulatories, in contrast, do require the use of wheelchairs as in cases of tetraplegia or paraplegia - this category can include the use of stretchers. The analysis also considered persons without mobility deficiencies like operations or medical personnel.

\section{Scenarios}

Considering that medical services are only provided with the ship moored or anchored, these conditions were taken as a starting point to establish the two moments that account for mobility activities: access, which contemplates the relationship with exterior processes of embarking or disembarking from water or land and interior circulation, which is the most adequate distribution according to the relationship between services and the dimension of compartments, doors, and corridors.

From these moments, it was established how the special conditions of ships limit the application of accessibility specifically in the case study, as shown by the following:

- Access: The RACC is a river ship that depends on the infrastructure of the Colombian hydrographic basins to moor; often these do not have a harbor or pier as access support, that is, the possibility exists that the floatation line is at land level; considering that the ship must

\footnotetext{
5 The term disability is not taken as reference because it includes other deficiencies that remain beyond the project's reach
} 
reach the highest possible number of populations, the distance between the line of flotation and the main main deck was taken as the maximum distance to allow boarding the ship, consolidating the most evident physical barrier.
In case river conditions do not permit the ship to reach the riverbank, an auxiliary boat is available to transport people to and from the ship to receive the required medical care.

Fig. 1. Boarding from land

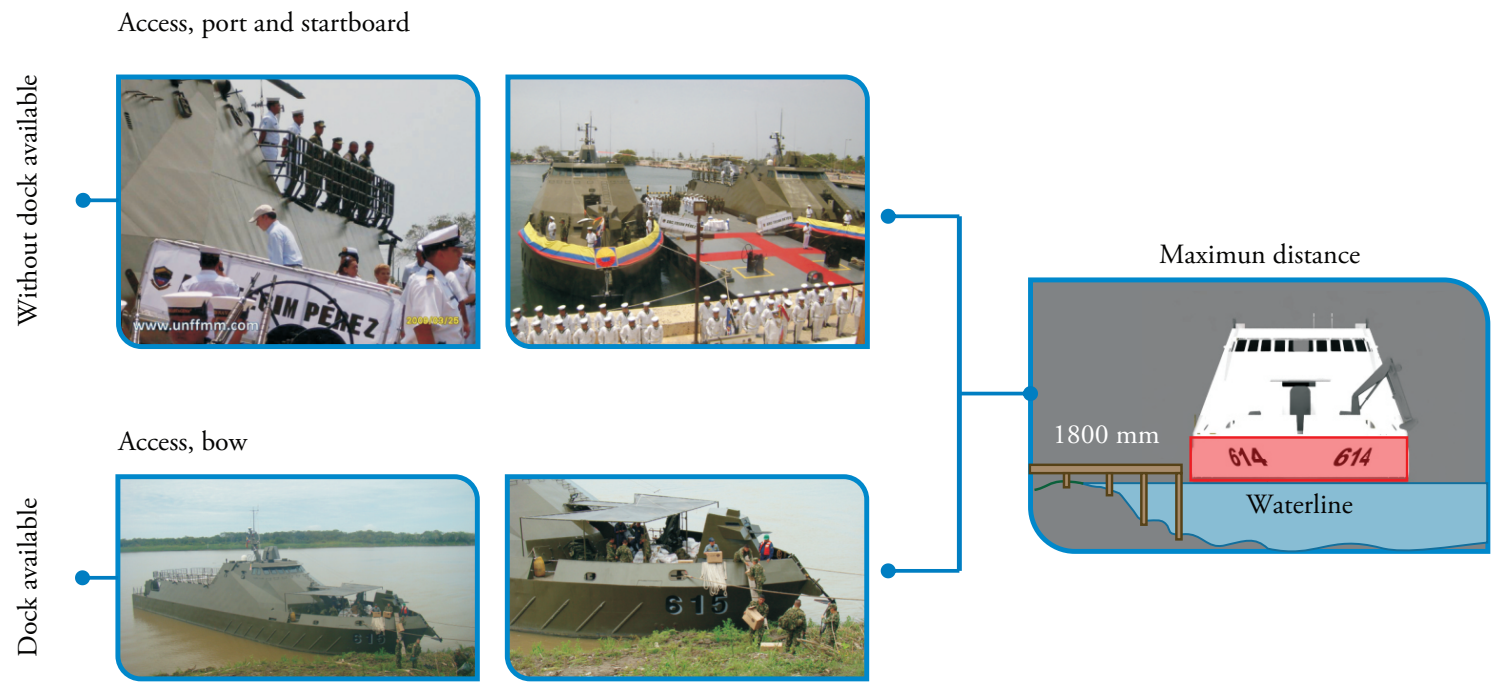

Fig. 2. Boarding from water

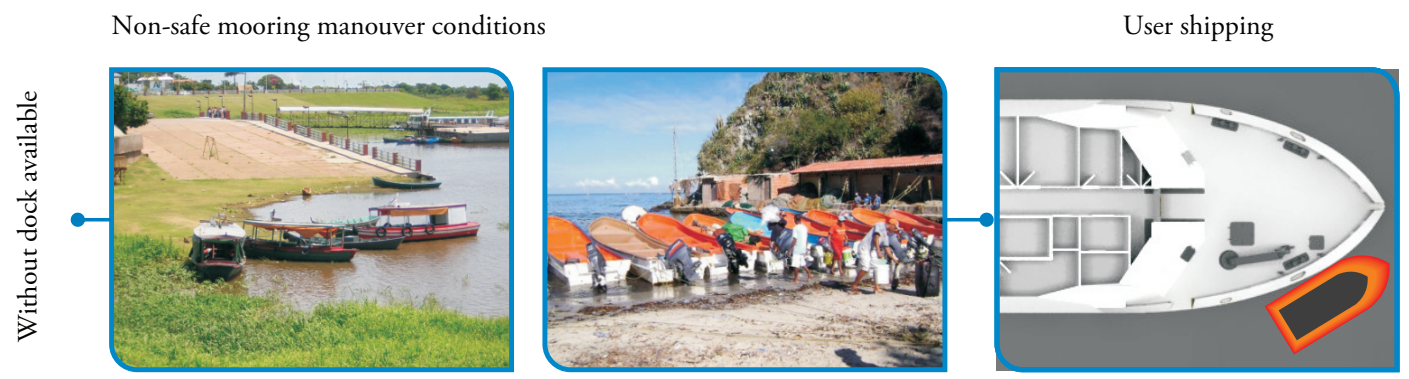

\section{Circulation}

The factor most affecting circulation within the ship is the reduced space, considering that it is a medical-type ship it is vital to provide adequate areas for each medical service and mobility among these that permits transit of wheelchairs and stretchers.
An additional factor that must be considered when analyzing accessibility is the means of evacuation; in case of emergency, the lives of patients and crew will depend on efficient evacuation routes. 
Fig. 3. Distribution of medical services, main deck

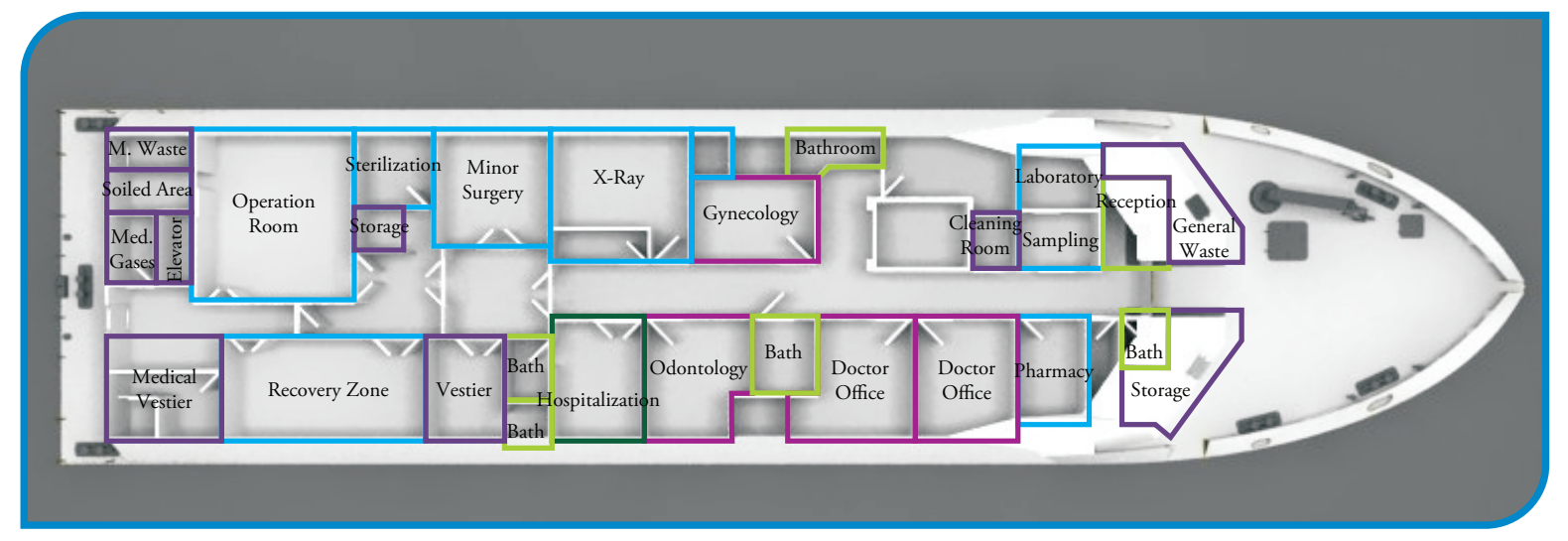

\section{Methodology}

The analysis and design process is part of the development of rehabilitation technologies (see item Accessibility, definition, and strategies), which is why it is pertinent to consider their strategies in applying accessibility criteria.

Fig. 4. Accessibility strategies

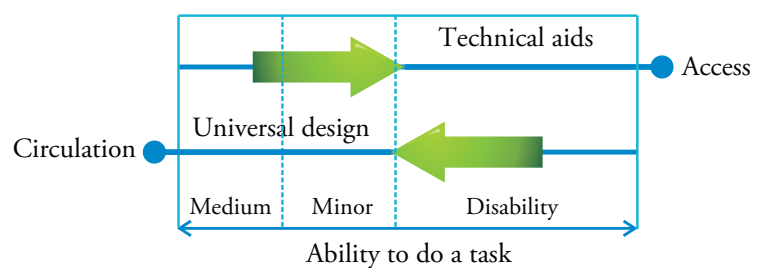

Source: (Ministry of Labor and Social Issues. Alonso, Fernando, 2003)

Different strategies were applied to both scenarios, access, design of technical aids and to circulation, universal design; apparently simpler and more functional would be to install a ramp, but demands of the context do not permit such with an adequate inclination for wheelchairs. The decision to undertake different strategies was made considering:

- Conditions for access from land are variable and depend on the place of birthing, although these could probably be optimal for an embarking system, they can turn out deficient for another, which is why it is important for the systems to be adaptable to the context.

- On the contrary, the interior is the context with the least physical barriers, which does not change due to external conditions; the problem here is to accomplish within a reduced space a correct relationship among the medical services according to their complementation, integration, or independence, which is why a universal solution is more viable; additionally, when taken as a means of reference in the design of the physical space it also permits passage of individuals without reduced mobility.

- It is difficult to estimate what physical limitations will be presented by users, which is why wheelchairs and stretchers were taken as main support products, given that they are essential for medical service care.

\section{Results}

Stemming from the analysis and by applying the aforementioned strategies, a system is proposed comprising various products to eliminate the embarking physical barriers during the boarding and circulation process.

Regarding access, the most important requirement 
is the system's adaptability to the context, leading to the proposal of three products located on the forecastle and that permit safe and comfortable boarding for all users: An 8-step self-leveling ladder that adapts to the height required for the place of arrival, a ladder for boarding from the water with the necessary height to board from an auxiliary boat and a support product designed specifically to board in a wheelchair and stretcher, which uses a crane as a lifting means, located thus:

Fig. 5. Disposition of access products, forecastle

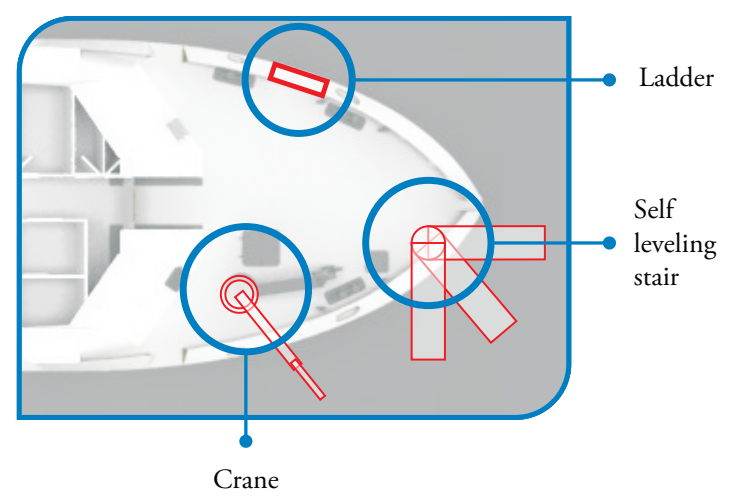

The location of the products is strategically designed to permit boarding via bow and starboard when boarding from land and via portside from the auxiliary boat.

The support product the crane uses as lifting system is a design by the DIDESI, developed within the framework of an internship in the equipment and habilitation Division, it was planned for efficiency by permitting boarding from water or land in wheelchair or stretcher, in addition to folding to reduce the space occupied when stored. It is versatile in that it allows the use of different wheelchairs and stretchers on the same platform.

The device secures the wheelchair or stretcher by means of two arms located on the upper part and secures patients with fastening belts that keep them stable, guaranteeing a safe lifting process. Finally, anthropometric and ergonomic criteria were considered (Universidad de Antioquia, 1995) for comfortable use of the product.

Fig. 6. Access support product for wheelchairs and stretchers
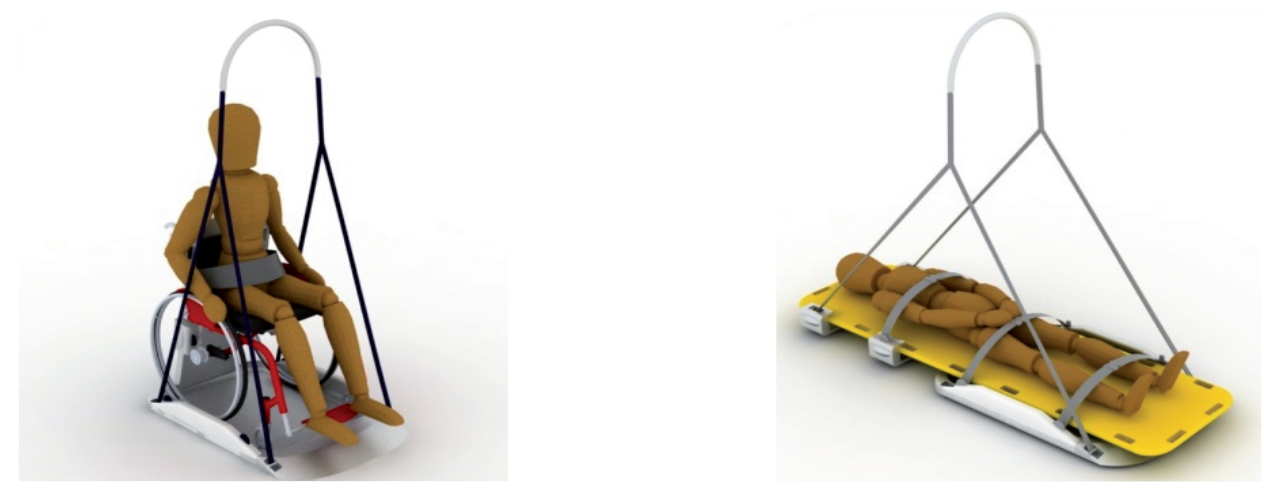

Fig. 7. Access support product, use angles
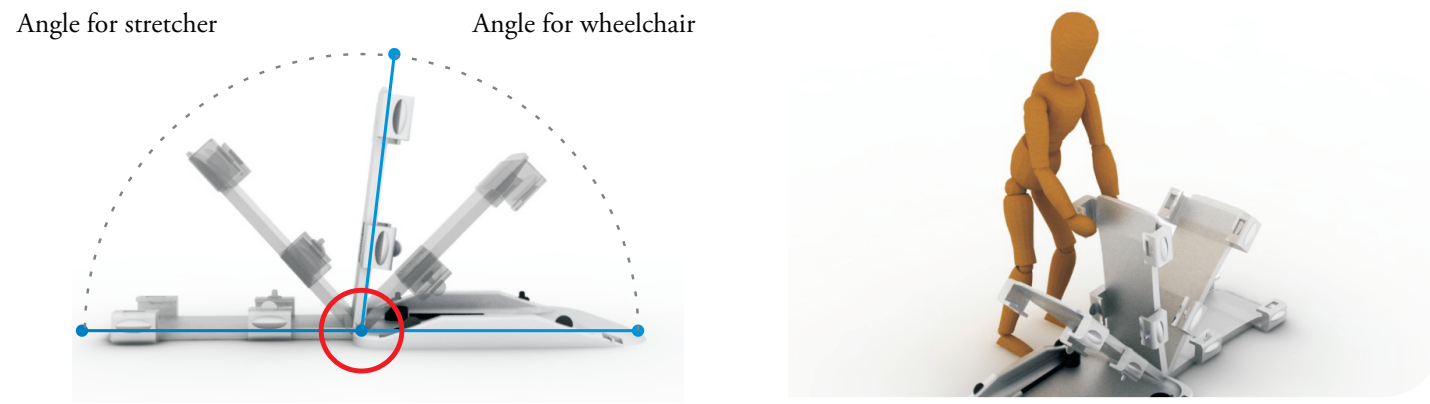

Source: Alatrista, 2008 
Fig. 8. Use sequence of access support product
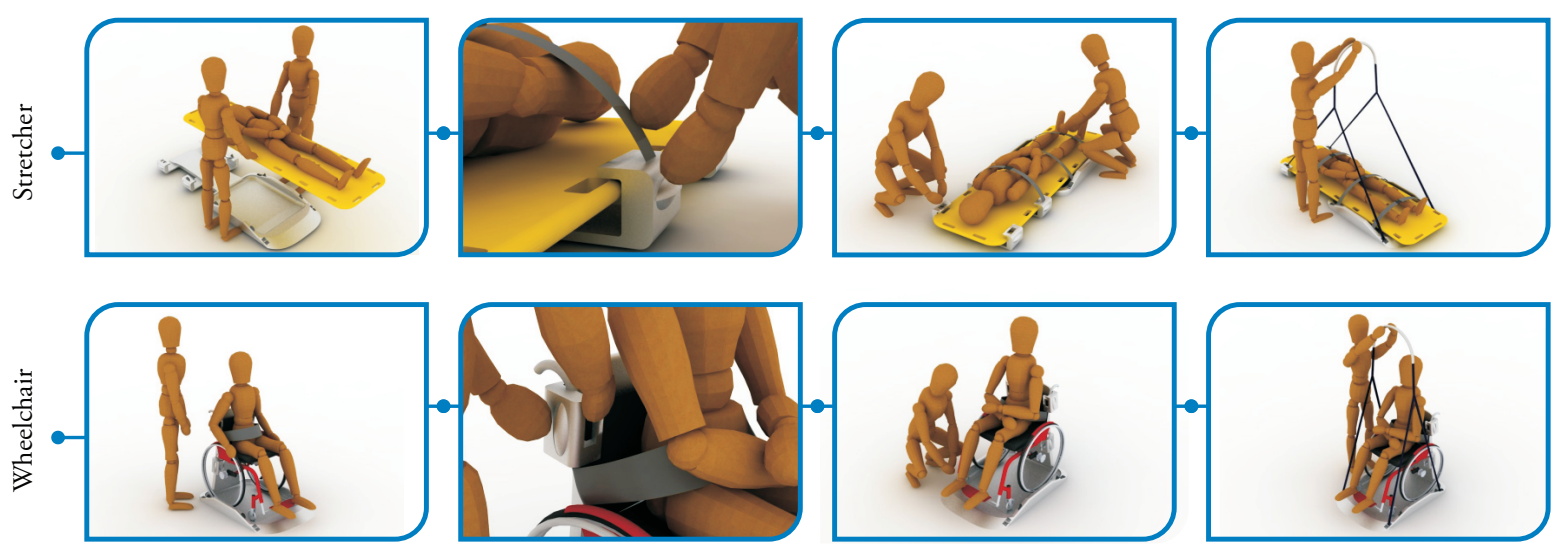

Source: Alatrista, 2008

For circulation, the first step was to establish the relationship among the medical services, this analysis was based on the study "Architectural Medical Program to Design Safe Hospitals" (Alatrista, 2008), which determines that among the services the following spatial links may be established (see Fig. 9 in pag. 18):

- Direct access: Units requiring to be located side by side to ensure rapid circulation, given the related tasks they perform.

- Immediate access: Units with complementary activities and which require having a rapid link for which they must have easy access and communication without necessarily being contiguous.

- Access: Units that perform related tasks, but do not require being near to each other or keep amongst them a relationship of easy communication.

- Independents (without relationship): Those without common tasks or activities

Adequate design of circulation ensures efficient movement of patients, personnel, visitors, as well as of materials and supplies, avoiding cross circulation (Alatrista, 2008). Additionally, it is worth considering some requirements of the medical structures like: protection of traffic in the surgery and emergency areas; crossing clean and dirty zones must be avoided, keeping hazardous wastes away from sterile zones; vertical circulation from and to the heliport, and the minimum area to provide a service.

From the aforementioned, the general arrangement was determined considering the flow of activities among compartments; for dimensioning, the regulatory reference was taken (ICONTEC, 2005) (Instituto Mexicano del Seguro Social, 2000), which suggests: minimum spaces for $90^{\circ}, 180^{\circ}$, and $360^{\circ}$ turns with wheelchairs and the minimum width of corridors and doors for passage of stretchers or wheelchairs, among others.

Services were also dimensioned; these are standardized by the Colombian Ministry of Social Protection (Ministry of Health, 1996) for land structures; however, the condition of reduced spaces within the ship does not permit the final areas to reach those required, which is why their size was reduced to the ergonomically and anthropometrically minimum necessary to develop activities in each compartment according to the service provided, considering that furnishings permit the ingress, turn, and exit of a wheelchair or a stretcher in spaces that so require it, as shown in Figs. 10 and 11 (see pag. 18). 
Fig. 9. Relationships among medical services

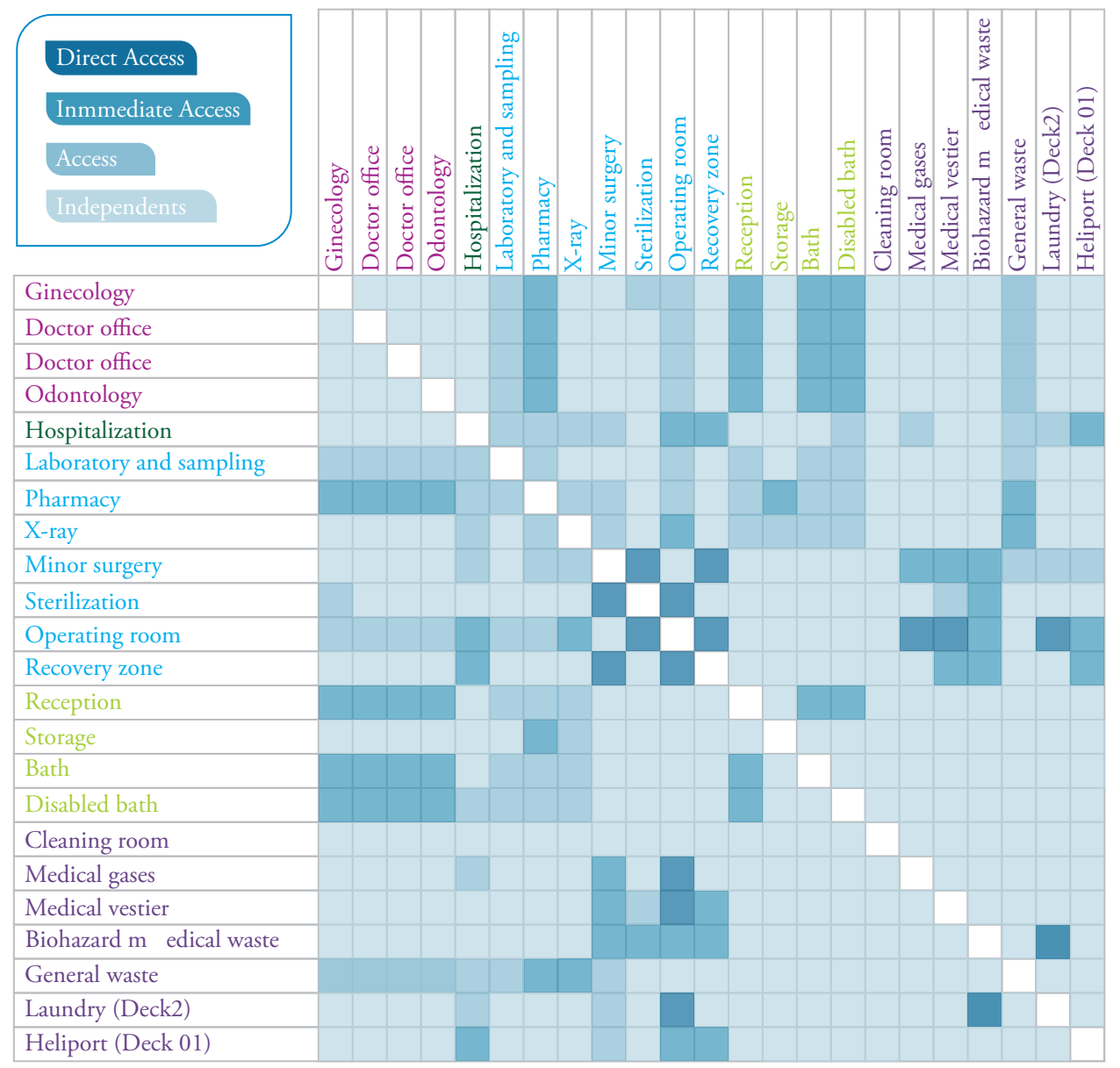

Source: Alatrista, 2008

Fig. 10. Wheelchair circulation

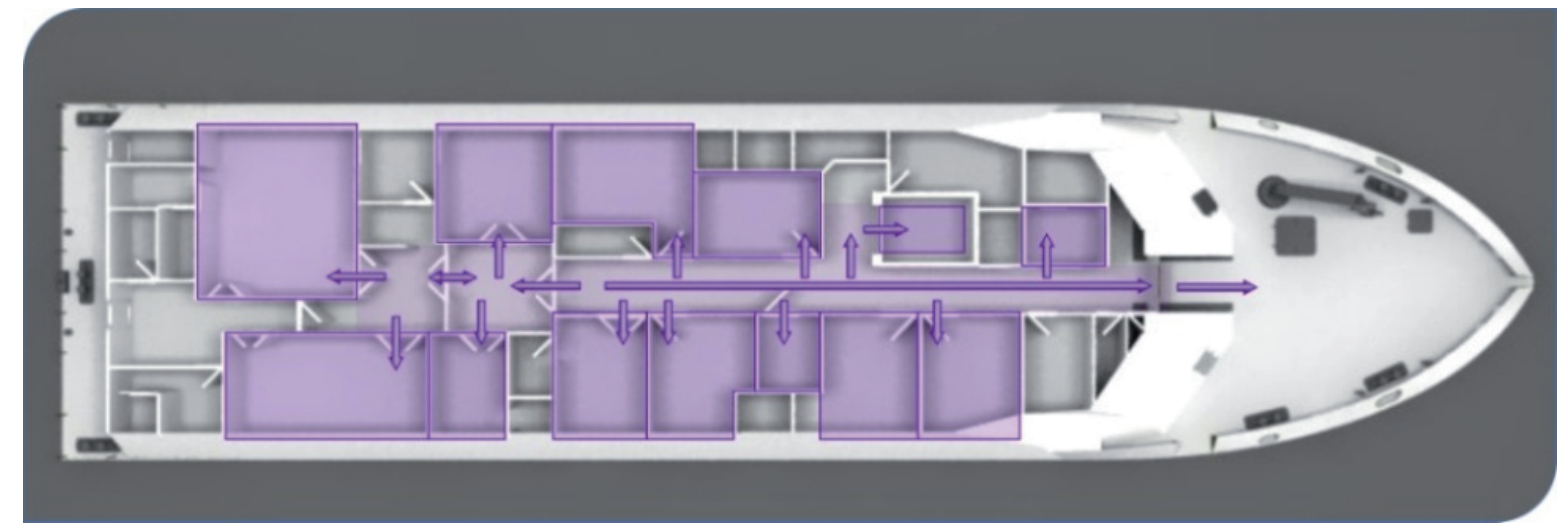


Fig. 11. Stretcher circulation

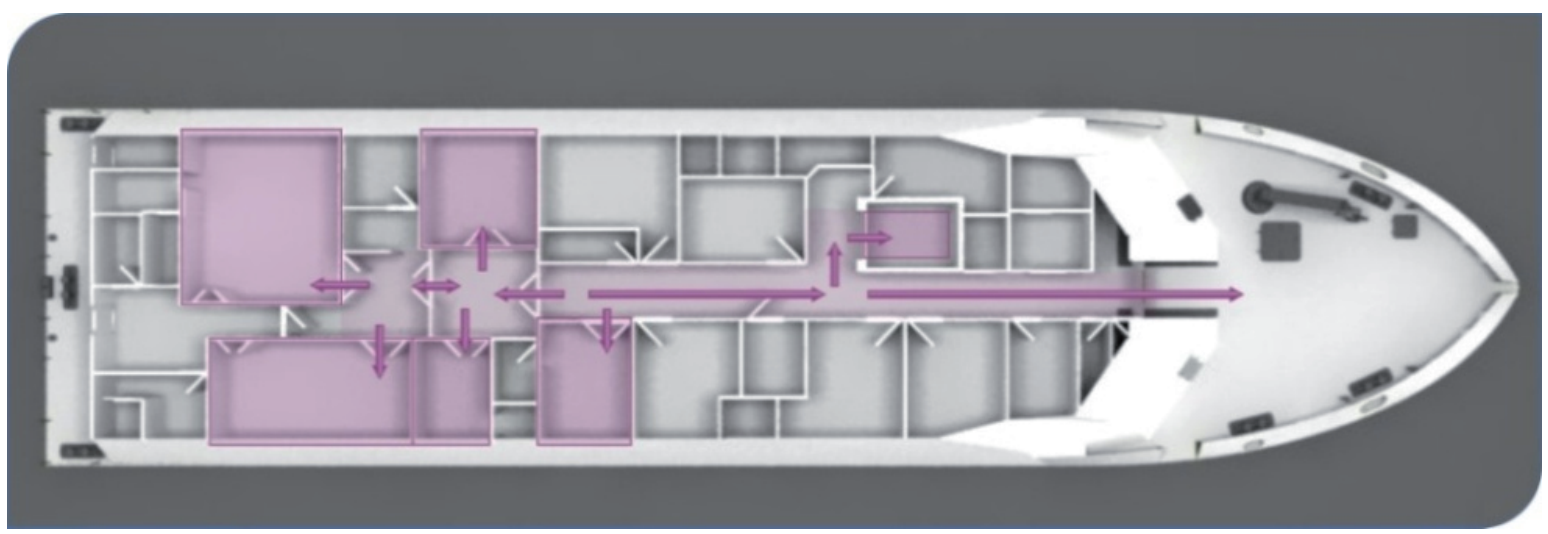

Adequate circulation of wastes is vital to provide a safe and aseptic environment, which is why two storage spaces are suggested while providing medical services: one for non-hazardous general wastes (green) and one for hazardous hospital wastes (red) resulting from surgical interventions.

Fig. 12. Management of wastes, sectors, and circulation routes

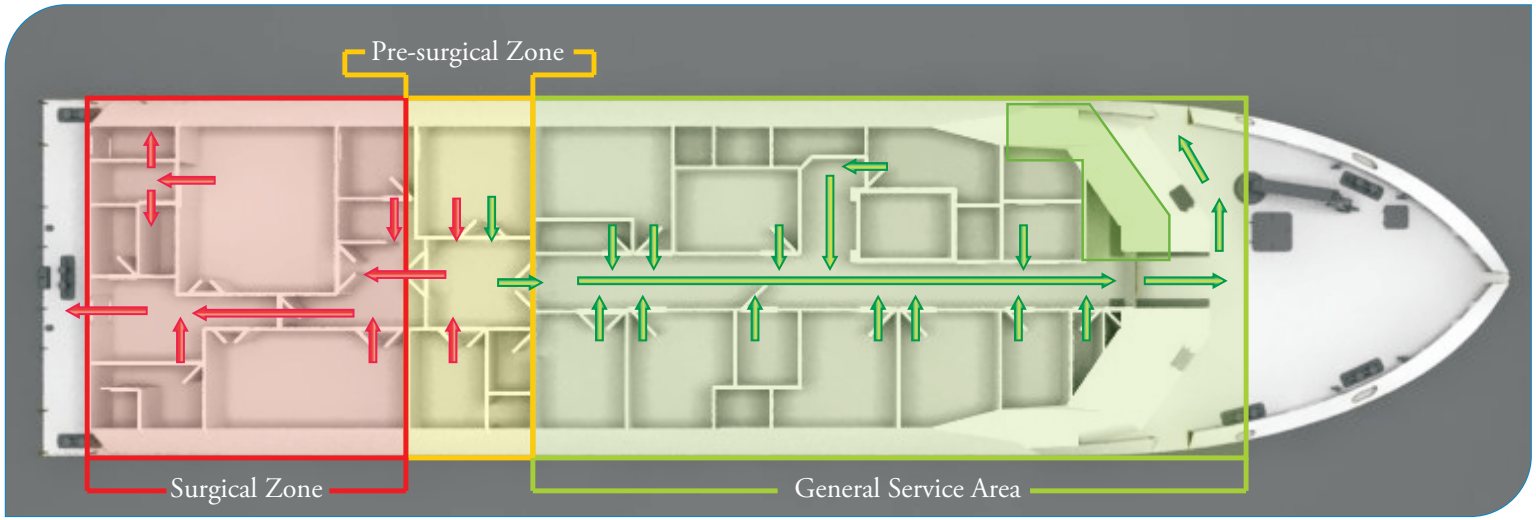

All this analysis and redesign process yielded as a result the conceptual design of the main deck as an accessible environment for wheelchair and stretcher mobility, which promotes social inclusion.

The other decks were not detailed given that patients are restricted from entering therein. The design was complemented with a system of products through which all persons - regardless of their physical condition - could safely and comfortably embark.

\section{Conclusions}

- Accessibility is not a widely studied issue in the Colombian naval industry; however, when considering it within the medical context it becomes essential and consolidated as a first step in studying the topic at the national level, which should not only be applied to ships where ingress is permitted to persons with reduced mobility; in ships in general it can contribute 
to optimize access to reduced spaces and to the reduction of risks during emergency cases through the arrangement of evacuation routes.

- Consideration of accessibility within the design process facilitated the elimination of environmental barriers, permitting comfortable access and circulation of persons with reduced mobility is spite of the variable context, promoting equality and social inclusion; concepts that have addressed considerably in the naval industry.

- Habitability in ships must be adapted to more specific requirements than a structure on land; occasionally, regulations leave a series of gaps where decisions must be made based on ergonomic and anthropometric criteria, as in the case of the space for medical spaces, where by studying in detail the relationships, activities, and processes it was possible to provide a solution, which although not being the recommended solution for a structure on land, permits optimally providing a service, ensuring rapid and efficient movement and communication of materials, inputs, and personnel among the medical units, besides adding conditions of bio-safety while providing medical services.

- The problem of accessibility is complex given the multiplicity of situations and variables that must be considered when evaluating its pertinence; some of these are evidenced in the case study; however, no methodology or standard exists to guide its approach. It is necessary to study each case in particular from a systemic view. This study can be taken as a reference of the analysis process.

\section{Recommendations}

- Analysis of accessibility in this study is limited to the conceptual design phase; it is recommended that subsequent design phases consider other variables like furnishings, medical equipment, and signposting for accessibility to be comprehensive.

- The accessibility standard applied in ships is scant or null in case of hospitals, which halts the development of proposals of great social contribution like the RACC; it is necessary to promote the standardization of this theme, promoting the development of the naval industry in this field.

\section{Bibliography}

ALATRISTA, C. B. (2008). Programa Médico Arquitectónico para el Diseño de Hospitales Seguros. Sinco editores.

ALONSO, F. (2007). Algo más que suprimir barreras: conceptos y argumentos para una accessibilidad universal. Trans. Revista de traductología 11.

ALONSO, F. (2007). Los ejes determinantes de las políticas de igualdad de oportunidades III, La accessibility universal y el diseño para todos. Tratado sobre la discapacidad.

AMENGUAL, C. (1996). Movilidad reducida y accesibilidad en Varios Autores, Curso Básico Sobre Accesibilidad al Medio Físico. Real Patronato de Prevención y Atención a Personas con Minusvalía, Madrid.

ICONTEC. (2005). Norma Técnica Colombiana 4140, Accesibilidad de las personas al medio físico. Edificios, pasillos y corredores. Características generales. Bogotá, Colombia.

INSTITUTO SUECO DE LAS MINUSVALÍAS. (1994). Study HEART (Horizontal European Activities in Rehabilitation Technology).

INSTITUTO UNIVERSITARIO DE ESTUDIOS EUROPEOS, UNIVERSIDAD AUTÓNOMA DE BARCELONA. (2002). Libro verde, La accesibilidad en España, 
diagnósticos y bases para un plan integral de supresión de barreras.

INSTITUTO MEXICANO DEL SEGURO SOCIAL. (2000). Normas para la accesibilidad de personas con Discapacidad.

MINISTERIO DE SALUD (1994). Resolución Número 5261 De Manual de Activities, Intervenciones y Procedimientos del Plan Obligatorio de Salud en el Sistema General de Seguridad Social en Salud. (MAPIPOS) . Colombia.

MINISTERIO DE SALUD. (1996). Resolución número 04445 de 1996 . Colombia.

MINISTERIO DE TRABAJO Y ASUNTOS SOCIALES. ALONSO, FERNANDO. (2003). Libro blanco de la accesibilidad, Plan de accesibilidad 2003-2010, ACCEPLAN.

NACIONES UNIDAS. (2007). Convención sobre los Derechos de las Personas con Discapacidad. Nueva York.
NORTH CAROLINA STATE UNIVERSITY. (1995). The Center for Universal Design: Universal Design.

COLOMBIA LÍDER, FUNDATION SALDARRIAGA CONCHA. (2010). Discapacidad en Colombia: retos para la inclusión en capital humano. Bogotá.

SMITH, R. W. (1987). Leisure of Disabled Tourists. Barriers to Participation.

UNIVERSIDAD DE ANTIOQUIA, INSTITUTO DE SEGUROS SOCIALES, JAIRO ESTRADA MUÑOZ. (1995). Parámetros Antropométricos de la Población Laboral Colombiana 1995 ACOPLA95. Medellín, Colombia. 